\title{
The causes and prevention of rolling bearing overheating of the axle box in the freight wagons while driving
}

\author{
Przyczyny i zapobieganie przegrzaniu łożysk tocznych w maźnicach \\ wagonów towarowych podczas jazdy
}

\begin{abstract}
The article presents the problems related to the reasons of rolling bearings overheating of the freight wagons during operation. This question is significant as being related to driving safety. It affects the safety of the rolling stock and railway infrastructure. Hence, it may be concluded that attention should be paid to the quality of the bearing node assembly and to a diagnostic system located along the railway infrastructure, designed to detect the overheated rolling bearings.

$W$ artykule przedstawiono problematykę zwiqzana $z$ przyczynami przegrzania tożysk tocznych $w$ wagonach towarowych podczas eksploatacji. Zagadnienie to jest o tyle ważne, że zwiqzane jest ono z bezpieczeństwem jazdy. Wplywa ono na bezpieczeństwo kursujacego taboru oraz infrastruktury kolejowej. Stąd wynika następny wniosek, aby zwrócić uwagę na jakość montażu węzła łożyskowego oraz na system diagnostyczny, przeznaczony do wykrywania przegrzanych tożysk tocznych, rozmieszczony wzdluż infrastruktury.
\end{abstract}

\section{INTRODUCTION}

Overheating of the rolling bearings installed in the axle box body of the standard Y 25 running gears of the freight wagons is a phenomenon known in the rail industry. It is a result of very different reasons and is considered to be highly dangerous if the released thermal energy causes the node temperature growth above the allowable value. Therefore, extensive diagnostics is necessary, both on the vehicle itself (i.e. on the freight car), and in the infrastructure. In order to determine properly the preventive and diagnostic measures, the knowledge of potential reasons of the phenomenon is necessary. This issue is even more important since, in accordance with the EU Directives, the infrastructure has been separated and considered to be independent from respective railway authorities, with a view to enhance competitiveness of the rail transport. The main intention of the legislator consisted in enlarging the right of particular carriers to access the rail infrastructure. This legislator's goal was properly justified but, at the same time, gave rise to the other side effects affecting the safety of the rolling stock and infrastructure. Such an EU decision led, in consequence, to increased expenditures for the rolling stock safety, in the form of growing financial resources for the rolling stock diagnostics and the railway surface quality. Long-lasting overheating of the rolling bearings may lead to tearing off the wheelset axle pivot and, in consequence, to wagon and the whole train derailment.

\section{WSTĘP}

Zjawisko przegrzania łożysk tocznych, zainstalowanych w korpusie maźnicy standardowych układów biegowych Y25 wagonów towarowych jest znane w kolejnictwie. Ma bardzo różne przyczyny i należy je jako takie zaliczyć do bardzo groźnych, jeśli wyzwalająca się energia cieplna, a wraz z nią temperatura węzła przekroczy wartości dopuszczalne. Dlatego też potrzebna jest dalece rozbudowana diagnostyka zarówno na pojeździe, w tym przypadku wagonie towarowym, jak również ze strony infrastruktury. Aby odpowiednio dobrać środki prewencyjne oraz diagnostyczne należy poznać potencjalne przyczyny omawianego zjawiska. Zagadnienie to jest tym bardziej istotne, gdy zgodnie z Dyrektywami UE, infrastruktura została wyodrębniona, jako niezależna $z$ poszczególnych zarząáw kolejowych w celu zwiększenia konkurencyjności transportu kolejowego. Głównym zamierzeniem ustawodawcy było zwiększenie prawa do dostępu poszczególnych przewoźników do infrastruktury kolejowej. Cel ustawodawcy jak najbardziej słuszny, spowodował jednak inne uboczne skutki, dotyczące bezpieczeństwa kursującego taboru oraz infrastruktury. Taka decyzja UE, prowadziła w konsekwencji do zwiększenia nakładów z obu stron na bezpieczeństwo kursującego taboru, w postaci kierowania coraz większych środków finansowych na diagnostykę kursującego taboru oraz jakości nawierzchni kolejowej. Zjawisko trwałego przegrzania łożysk tocznych może prowadzić do ukręcenia czopa osi zestawu ko- 


\section{DESCRIPTION OF THE CAUSES OF ROLLING BEARING OVERHEATING IN THE FREIGHT WAGONS RUNNING GEARS}

\subsection{THE ROLLING BEARING ASSEMBLY} MOUNTED IN THE AXLE BOX

The structure of the axle box node of the Y25 family running gears is shown in Figs 1 and 2. The first structure, shown in Fig. 1, is a standard one, adopted in the regular ORE/ERRI/UIC documentation. What relevantly distinguishes this solution is the use of a felt sealing ring. It was discussed in $[1,2]$ and cannot be well evaluated, from the point of view of its functionality, quality and reliability. The node shown in Fig. 2 provided with a labyrinth sealing ring is a much better solution. Similar seals are used in axle box nodes of domestic and foreign locomotives.

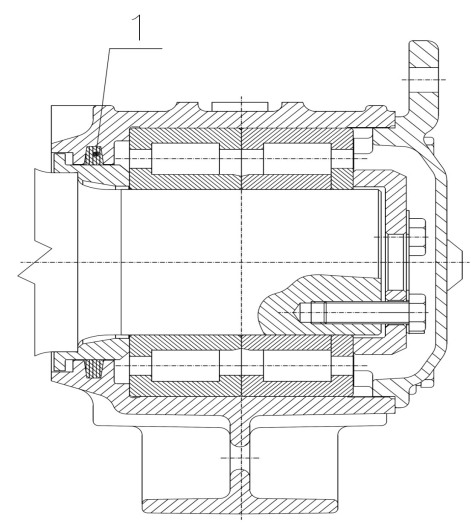

Fig. 1. An axle box body of a Y25 running gear provided with a felt seal

Legend:

$1-$ a felt ring

Rys. 1. Korpus maźnicy układu biegowego rodziny Y25 z uszczelLegenda:1-pierścień filcowy nieniem filcowym

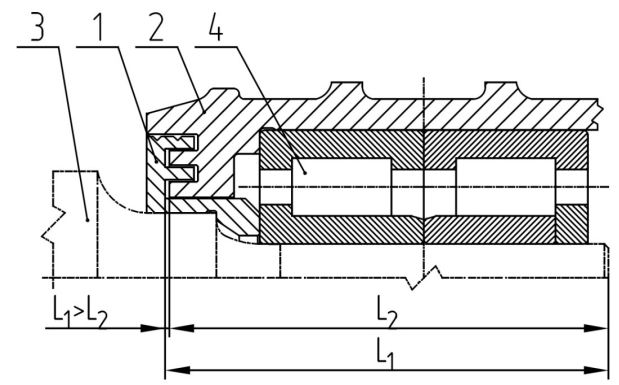

Fig.3. A detail of the labyrinth seal of the axle-box of the Y25 running gear .Legend: 1-labyrinth ring, 2-axle box body, 3wheelset axle, 4- a part of the cylindrical roller bearing unit

Rys.3. Szczegół przedstawiający uszczelnienie labiryntowe maźnicy układów biegowych Y25 Legenda: 1-pierścień labiryntowy, 2korpus maźnicy, 3-oś zestawu kołowego, 4-zespół łożysk walcowych (fragment)

In case of the labyrinth seal the standard axle box body of the Y25 running gear designed for a freight car must be subjected to special processing. A detail of the labyrinth seal solution is shown in Fig. 3. łowego, a w następstwie do wykolejenia wagonu (pociagu towarowego).

\section{OPIS PRZYCZYN PRZEGRZEWANIA SIE LOŻYSK TOCZNYCH W UKLADACH BIEGOWYCH WAGONÓW TOWARO- WYCH}

\subsection{UKLAD ZABUDOWY LOŻYSK TOCZ- NYCH W MAŹNICACH}

Konstrukcja węzła maźniczego układów biegowych rodziny Y25 jest przedstawiona na rys. 1 i rys. 2. Pierwsza konstrukcja, przedstawiona na rys. 1 jest konstrukcją standardowa, przyjętą $\mathrm{w}$ dokumentacji standardowej ORE/ERRI/UIC. Istotną cechą wyróżniająca jest zastosowanie pierścienia filcowego jako pierścienia uszczelniającego. Rozwiązanie to było omówione w publikacji $[1,2]$ i z punktu widzenia funkcjonalności, jakości oraz niezawodności nie może być dobrze ocenione. Znacznie lepszym rozwiązaniem jest węzeł konstrukcyjny przedstawiony na rys. 2, gdzie jako uszczelnienie jest zastosowany pierścień labiryntowy. Podobne uszczelnienia stosuje się w węzłach maźniczych lokomotyw krajowych oraz zagranicznych.

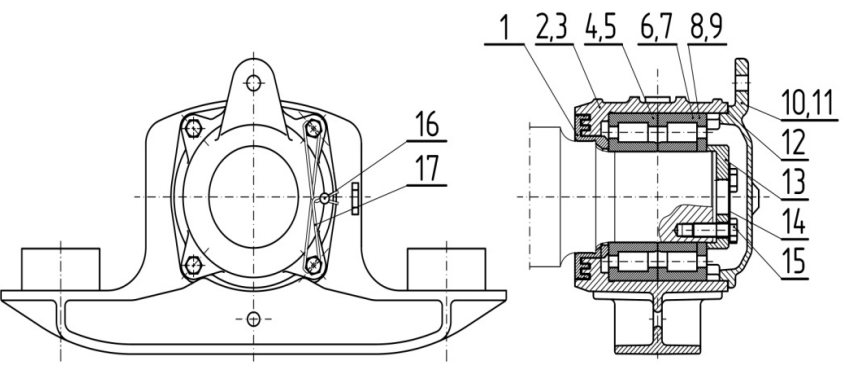

Fig. 2. An axle box body of a Y25 running gear provided with a labyrinth seal

Legend:

1-thrust ring, 2,3-two variants of the axle box body, 4,5- TBU $130 \times 240 \times 160$ bearing unit, $6,7-\mathrm{WJ}+\mathrm{WJP} 130 \times 240$ cylindrical roller bearing unit, 8,9- NJ+NJP GMC4 cylindrical roller bearing unit, 10,11-front cover, 12-rubber seal, 13-front ring, 14- lock washer,15-screw, 16-plug, 17-steel wire

Rys. 2. Korpus maźnicy układu biegowego rodziny Y25 z uszczelnieniem labiryntowym

Legenda:

1-pierścień oporowy, 2,3-korpus maźnicy w dwóch wariantach wykonawczych, 4,5-zespół łożyskowy TBU 130×240×160, 6,7zespół łożysk walcowych WJ+WJP 130×240, 8,9- zespół łożysk walcowych NJ+NJP GMC4, 10,11-pokrywa przednia, 12uszczelka gumowa, 13-pierścień przedni, 14- podkładka zabezpieczająca,15- śruba, 16-plomba, 17-drut stalowy

Uszczelnienie labiryntowe wymaga praktycznie innej obróbki standardowego korpusu maźnicy układów biegowych rodziny Y25, przeznaczonych dla wagonów towarowych. Szczegół rozwiązania z uszczelnieniem labiryntowym został przedstawiony na rys. 3 . 
2.2. THE REASONS FOR TEMPERATURE INCREASE OF THE ROLLING BEARINGS IN THE Y25 RUNNING GEAR WHEELSET AXLE BOX

The factors contributing to the increase in bearing operating temperature above the allowable level can be determined by analyzing Figs 1-3. The bearing temperature may reach the values endangering its safe operation if the bearings are incorrectly assembled, i.e. not in accordance with the mounting instructions provided by the bearing manufacturer. For correct assembly of the axle box, all the dimensions and tolerances, as well as the deviations in shape and position of the following components must be met, i.e .:

$>$ the pivot and wheelset axle collar;

$>$ the axle box body, especially the outer bore diameter $\phi 240 \mathrm{H} 7$;

$>$ the labyrinth ring;

$>$ the pressure ring;

$>$ the front cover;

$>$ cylindrical roller bearings $\mathrm{NJ}+\mathrm{NJP}$ $120 \times 240 \times 80$ and $\mathrm{WJ}+\mathrm{WJP} 120 \times 240 \times 80$ of the A-type axles, cylindrical roller bearings NJ+NJP $130 \times 240 \times 80$ and WJ+WJP $130 \times 240 \times 80$ of the B-type axles (the axle type is listed in the UIC 510-1 [26] leaflet).

Overall, all the components must comply with the design documentation. The dimensions of some of the parts may change during operation. It occurs, first of all, in the case of wearing of the outer surface of the axle pivot (the damages in the form of scratches), caused by removal and reassembly of the inner rings of the bearings, and wearing of the axle collar, caused by removal and reassembly of the thrust rings. This results in the use of the so-called "undersized" bearings, having the inner ring diameter of $118 / 119 \mathrm{~mm}$ in case of the A-type axles and 128/129 $\mathrm{mm}$ in case of the B-type axles. Acceptable wear of the wheelset axle collar diameter should be specified in the design documentation. Allowable minimum dimensions of the axle pivot diameter and the axle collar diameter must be confirmed by calculation according to the methodology defined in PN-EN 13103-1: 2018 [6] and in the works $[3 \div 5]$. It should be taken into account that the force necessary to remove the inner ring exceeds the pressing force while assembling, moreover, the ring material is much harder than the one of the axle. It should also be noted that the best method of axle inner ring embedding consists in its induction heating with simultaneous cooling of the axle shaft with liquid nitrogen (if possible). Removal of the inner rings is recommended for several reasons, including observation of contact corrosion and possible magneticparticle and ultrasonic tests. Therefore, the manufacturer's assembly is the first step to achieve the intended goal of correct assembly of the bearing node while repairing. These procedures are repeated during the

\subsection{PRZYCZNY PODWYŻSZENIA TEMPERA- TURY LOŻYSK TOCZNYCH W MAŹ- NICACH ZESTAWÓW KOLOWYCH UKŁADÓW BIEGOWYCH Y25}

Czynniki podwyższające prace łożyska, ponad dopuszczalną można określić, analizując rys. $1 \div 3$. Temperatura łożysk, może osiagnąć wartości zagrażające bezpiecznej eksploatacji, jeśli montaż łożysk nie jest prawidłowy, a więc nie przeprowadzono go zgodnie $\mathrm{z}$ instrukcję montażu producentów łożysk. Aby montaż węzła maźniczego odbył się w sposób prawidłowy muszą być dotrzymane wszystkie wymiary wraz z tolerancjami oraz odchyłki kształtu i położenia części składowych tzn.:

$>$ czopa i przedpiaścia osi zestawu kołowego

$>$ korpusu maźnicy, zwłaszcza zewnętrznej średnicy otworu $\phi 240 \mathrm{H} 7$

$>$ pierścienia labiryntowego

$>$ pierścienia dociskowego

$>$ pokrywy przedniej,

$>$ łożysk walcowych NJ+NJP $120 \times 240 \times 80$ oraz WJ+WJP $120 \times 240 \times 80$ dla osi typu A łożysk walcowych NJ+NJP $130 \times 240 \times 80$ oraz WJ+WJP $130 \times 240 \times 80$ dla osi typu B (typ osi jest wymieniony w karcie UIC 510-1 [28]).

Reasumując wszystkie elementy składowe muszą być zgodne $\mathrm{z}$ dokumentacją konstrukcyjna. $\mathrm{W}$ trakcie eksploatacji, ale również i napraw, wymiary niektórych części mogą ulec zmianie. Dotyczy to przede wszystkim zużycia (uszkodzenia w postaci rys, zarysowań) powierzchni zewnętrznej czopa osi, wskutek demontażu mechanicznego (za pomocą ściagaczy mechanicznych oraz hydraulicznych) i ponownego montażu pierścieni wewnętrznych łożysk oraz przedpiaścia osi wskutek demontażu i ponownego montażu pierścieni oporowych. Wynika stąd zastosowanie tzw. łożysk „podwymiarowych” o średnicy pierścienia wewnętrznego 118/119 mm dla osi typu A oraz 128/129 mm dla osi typu B. Dopuszczalne zużycie średnicy przedpiaścia osi zestawu kołowego należy podać w dokumentacji konstrukcyjnej.

Dopuszczalne minimalne wymiary średnicy czopa i przedpiaścia osi zestawu kołowego muszą być potwierdzone obliczeniowo zgodnie z metodyką przyjęta w PN-EN 13103-1:2018 [6] i w opracowaniach [3 $\div 5$ ]. Należy wziąć pod uwagę, że siły „stłaczania” pierścieni wewnętrznych są większe, aniżeli siła wtłaczania oraz materiał pierścieni posiada zdecydowanie większą twardość niż materiał osi. Jednocześnie należy zwrócić uwagę na fakt, że na pewno lepszą metoda osadzenia pierścieni wewnętrznych osi jest metoda podgrzewania indukcyjnego (niem. „Induktives Anwärmen"), z jednoczesnym chłodzeniem czopa osi za pomocą ciekłego azotu (jeśli to możliwe).

Demontaż, określany w kolejowej technice warsztatowej jako „stłaczanie” pierścieni wewnętrznych jest wskazane z kilku względów, które sprowadzają się do 
operation in the course of the repairs carried out in accordance with the adopted Maintenance Documentation (MD).

Thus, the factors that can increase the bearing temperature above the allowable level may be divided into the following groups, i.e.:

$>$ a group of factors related to incorrect mounting of the bearings, that may lead to wrong longitudinal and radial construction clearances, resulting in invalid bearing operation;

$>$ a group of factors related to incorrect disassembly of the axle box parts, leading to their damage and wrong qualification,

$>$ a group of factors related to the lubricant type used, and its quantity;

$>$ the factors related to wrong sealing, resulting in lubricant leakage;

$>$ the factors related to defective manufacturer's production of particular parts;

$>$ the factors related to the operation on the tracks of various maintenance conditions, from very good to bad track;

$>$ the factors related to possible electric current flow, i.e. so-called stray current flowing through particular parts, especially through the bearing units,

$>$ tightness of the bearing node during operation, especially in terms of atmospheric pollution (penetration of fine particles, dust and sand) as well as uncontrolled grease leakage. These contaminants are also caused by the particles emitted in result of wear and tear of the brake blocks (e.g. made of GG ductile cast iron), and by the presence of quartz resulting from use of sand during start-up of the traction vehicles).

It might be concluded that the use of the bearings meeting the PN-EN 12080: 2017 [7] standard and the lubricants meeting the PN-EN 12081: 2017 [8] standard, together with operational tests complying with PN-EN 12082: 2017 [9] should reduce the risk of heating of the bearings. Such a view could be accepted, but with certain exceptions. Nevertheless, it should be taken into account that the tests complying with the above-mentioned standards are considered as typeapproval tests, while the bearing node is subjected to mandatory repairs and, for example, simplified ultrasonic tests of the wheelset axle. Such an operation requires removal of the front cover and thrust ring and their reassembly under field conditions. Therefore, it is exposed to "service errors", or the errors resulting from incorrect operation or wrong qualification for or after the repair. The unit undertaking the repair of the axle box node of the running gear (or suspension) of the freight wagon is paradoxically confronted with a more difficult task than the rolling stock manufacturer, as the latter has access to full construction documentation, the Technical Requirements for Manufacturing obserwacji zjawiska korozji stykowej oraz możliwości przeprowadzania badań magnetyczno-proszkowych oraz ultradźwiękowych. Tak więc montaż u producenta jest pierwszym etapem do osiagnięcia zamierzonego celu, jakim jest prawidłowy montaż węzła łożyskowego podczas napraw. Operacje te są powtarzane w eksploatacji $\mathrm{w}$ trakcie przeprowadzonych napraw zgodnie z przyjętą Dokumentacją Stanu Utrzymania (DSU).

Tak więc czynniki, które mogą zwiększyć temperaturę łożyska ponad stan dopuszczalny można sklasyfikować na poszczególne grupy i tak:

$>$ grupa czynników związanych z nieprawidłowym montażem łożysk, który może spowodować nieprawidłowe luzy konstrukcyjne wzdłużne oraz promieniowe, a tym samym nieprawidłową pracę łożyska

$>$ grupa czynników związanych z nieprawidłowym demontażem elementów maźnicy, doprowadzającym do uszkodzenia części, a następnie do ich nieprawidłowej kwalifikacji

$>$ grupa czynników związanych z zastosowanym rodzajem smaru oraz jego ilością

$>$ czynniki związane $\mathrm{z}$ nieprawidłowym uszczelnieniem, prowadzącym do wycieku smaru

$>$ czynniki związane $\mathrm{z}$ nieprawidłowym wykonaniem poszczególnych części, przez producenta (producentów)

> czynniki związane $\mathrm{z}$ eksploatacją na torze o bardzo dobrym, dobrym, średnim i złym stanie utrzymania

$>$ czynniki związane $\mathrm{z}$ ewentualnym przepływem prądu elektrycznego tzw. prądy błądzące przepływające przez poszczególne części, zwłaszcza zespoły łożyskowe

$>$ szczelność węzła łożyskowego podczas eksploatacji, zwłaszcza jeśli chodzi o zanieczyszczenia atmosferyczne (wnikanie drobnych cząstek zanieczyszczeń, pyłu, kurzu, piasku) jak również niekontrolowanym wyciekiem smaru; zanieczyszczenia te są związane również z emisją zużycia wstawek hamulcowych (np. wykonanych z żeliwa sferoidalnego GG), obecnością kwarcu jako efektu piaskowania podczas rozruchu pojazdów trakcyjnych).

Dokonując klasyfikacji można sądzić, że stosując łożyska, które spełniają normę PN-EN 12080:2017[7] i smary spełniające normę PN-EN 12081:2017 [8] oraz przeprowadzając badania eksploatacyjne wg normy PN-EN 12082:2017 [9] zmniejsza się ryzyko grzania łożysk. Można by zgodzić się z tym poglądem, z pewnymi jednak zastrzeżeniami. Należy wziąć pod uwagę, że badania wg wyżej wymienionych norm są badaniami homologacyjnymi, natomiast węzeł łożyskowy jako taki podlega obligatoryjnym naprawom oraz np. uproszczonym badaniom ultradźwiękowym osi zestawu kołowego, a operacja ta wymaga $\mathrm{z}$ kolei demonta- 
and Acceptance, Bearing Assembly Instructions and trained staff. Meanwhile, some of the carriers do not have their own repair shops. One of the solutions would consist in adoption of the principle that the rolling stock manufacturer's facility undertakes to carry out the periodic inspections and repairs. This approach has been used for years. However, such a principle does not eliminate the problem nor solves it completely. On the other hand, the repair plants have extensive experience in the field of technology for the used rolling stock repairs, and this ability has been systematically improved for years. It should be noticed that the bearing node is an unsprung mass, exposed, in consequence, to shock loads and extraordinary loads, referred to in the PN-EN 14363: 2019 standard [10]. One can assume that the wheel can be loaded with a vertical force:

where:

$$
\mathrm{Q}_{\mathrm{MAX}}=\mathrm{Q}_{0}+90
$$

$>\mathrm{Q}_{0^{-}}$the maximum static force acting on the wheel of a freight wagon subjected to maximum load;

$>90 \mathrm{kN}-$ maximum dynamic surplus in $[\mathrm{kN}]$.

In the case of freight wagons of allowable wheelset pressure on the track of $22.5 \mathrm{t}(220 \mathrm{kN})$, the maximum static load per a wheel amounts to $11.25 \mathrm{t}(110 \mathrm{kN})$.

Such a vertical force is also applied to the adjacent axle bearing node (disregarding the wheelset mass).

One can assume that the bearing node is subjected to lateral force $\mathrm{H}$, which is determined from the formula:

$$
\mathrm{H}_{\mathrm{j} . \max }=\mathrm{k}_{2} \cdot\left(10+\mathrm{P}_{\mathrm{FO}} / 3\right)
$$

where:

$>\mathrm{k}_{2}=0,75$ in case of an empty freight wagon;

$>\mathrm{k}_{2}=0,80$ in case of a loaded freight wagon

$>10 \mathrm{kN}$ - railway track resistance to lateral displacement and

$>\mathrm{P}_{\mathrm{FO}}=220 \mathrm{kN}$, maximum static wheelset load on a track.

$$
\mathrm{H}_{\mathrm{j} \cdot \max }=0,80 \cdot(10+220 / 3)=66,66 \mathrm{kN}
$$

Taking into consideration the forces that may be applied to the bearing node, one could conclude that its proper technical condition is significant from the point of view of the driving safety. One of the signs of wrong technical condition is an increase in the operating temperature of the bearing node above the limit of safe operation. The reasons for such a condition, already classified above, convert themselves to increased bearing operating resistance (e.g. as a result of reduced longitudinal and transverse clearance values of the bearing system) as compared to the normal operation. As a result of the increased work of friction, the temperature of particular bearing parts (i.e. the rollers, retainers) and the grease increases. This leads, żu pokrywy przedniej, pierścienia dociskowego oraz ponownego montażu w warunkach ,poligonowych.” Jest więc narażony na „błędy serwisowe”, albo inaczej błędy związane $\mathrm{z}$ niewłaściwą obsługą lub złą kwalifikacją do naprawy lub po przeprowadzonej naprawie.

Paradoksalnie naprawiający węzeł maźniczy układów biegowych (lub zawieszeń) wagonów towarowych ma trudniejsze zadanie niż producent taboru kolejowego, gdyż ten drugi dysponuje pełną dokumentacją konstrukcyjną oraz Warunkami Technicznymi Wykonania i Odbioru, Instrukcją Montażu Łożysk, przeszkoloną kadra, natomiast niektórzy przewoźnicy nie posiadaja własnych warsztatów naprawczych. Pewnym rozwiązaniem byłoby przyjęcie zasady, że zakład produkujący tabor kolejowy jest jednocześnie zakładem przeprowadzającym przeglądy oraz naprawy okresowe. Taka praktyka jest stosowana od lat. Jednak tak przyjęta zasada wcale nie rozwiązuje problemu, tak aby wyeliminować do końca problem lub całkowicie go rozwiązać. Zakłady naprawcze z kolei mają bardzo duże doświadczenie $\mathrm{w}$ zakresie technologii napraw eksploatowanego taboru, a wiedza ta jest gromadzona systematycznie od lat. Należy zwrócić uwagę, że węzeł łożyskowy jest węzłem nieusprężynowanym i jest narażony na obciążenia udarowe oraz obciążenia nadzwyczajne, które wynikają $\mathrm{z}$ normy PN-EN 14363+A1:2019 [10].

Jeśli przyjać, że koło może być obciążone siłą pionową:

gdzie:

$$
\mathrm{Q}_{\mathrm{MAX}}=\mathrm{Q}_{0}+90
$$

$>\mathrm{Q}_{0}$-maksymalna siła statyczna, działająca na koło wagonu towarowego załadowanego do maksymalnej granicy ładownej

$>90 \mathrm{kN}$ - maksymalna nadwyżka dynamiczna $\mathrm{w}[\mathrm{kN}]$,

to w przypadku wagonów towarowych o dopuszczalnym nacisku zestawu kołowego na tor, wynoszącym $22,5 \mathrm{t}(220 \mathrm{kN})$, maksymalny nacisk statyczny przypadający na koło wynosi $\mathrm{Q}_{0=} 11,25 \mathrm{t}(110 \mathrm{kN})$, a maksymalna siła, działająca na układ łożyskowy, wynosi zgodnie z zależnością (1) $\mathrm{Q}_{\mathrm{MAX}}=200 \mathrm{kN}$.

Taka też siła pionowa działa na sąsiedni maźniczy układ łożyskowy (pomijając masę zestawu kołowego). Jeśli przyjąć, że na układ łożyskowy działa poprzeczna siła $\mathrm{H}$, którą wyznacza się ze wzoru:

gdzie:

$$
\mathrm{H}_{\mathrm{j} . \max }=\mathrm{k}_{2} \cdot\left(10+\mathrm{P}_{\mathrm{FO}} / 3\right)
$$

$>\mathrm{k}_{2}=0,75$ dla wagonu towarowego $\mathrm{w}$ stanie próżnym

$>\mathrm{k}_{2}=0,80$ dla wagonu towarowego $\mathrm{w}$ stanie ładownym

$>10 \mathrm{kN}$ - opór toru kolejowego na przesunięcia poprzeczne

$>\mathrm{P}_{\mathrm{FO}}=220 \mathrm{kN}$, maksymalny nacisk statyczny zestawu kołowego na tor, 
on the one hand, to gradual loss of lubricating properties (increased friction work), and on the other, may contribute to minor but increasingly propagating bearing damages, that in turn may result in formation of wear metal filings in the lubricant and its gradual contamination. Based on the above it may be concluded that all the factors (or their combination) giving rise to increased frictional resistance in result of excessive wear, lead to the temperature increase of the bearing node. Cleanliness of the lubricant throughout its whole service life is important, provided that it might be considered as part of the design documentation. The bearing manufacturers make use of the $s$ purity factor and its effect on bearing service life. In order to determine the purity factor, the impurity factor $\mathrm{V}$ is necessary (i.e. normal purity $\mathrm{V}=1$, enhanced purity $\mathrm{V}=0.5$, the highest purity $\mathrm{V}=0.3$ ), provided that the bearing elements wear is considered as a normal phenomenon under the field (non-stationary) operation.

\subsection{DIAGNOSIS MEASUREMENTS OF THE AXLE BOX TEMPERATURE OF Y25 RUNNING GEARS OF FREIGHT WAG- ONS WITH THE USE OF TRACK-SIDE EQUIPMENT}

Analysis of the bearing node structure and operating conditions of the freight wagons, enables to increase their overhauling period. It is virtually impossible to trace the bearing node temperature "on-line" (i.e. on the freight car board ) in freight cars today's design. According to former railway regulations (already withdrawn), e.g. in UIC 579-2 [29] code, one of the methods for overheated bearing detection consists in manual checking of the bottom of the axle box body by the wagon inspector. Once the hand may be held for longer time, the bearing is considered suitable for further service. Otherwise, the wagon should be excluded from service with a view to conduct a thorough inspection. This method was subjective and very laborconsuming, taking into account the whole inspection work to be performed prior to the freight train clearance, although may be useful in diagnostics and used nowadays. It seems that the only effective method consists in construction of a diagnostic system (HABD - Hot Axlebox Detector) implemented by particular railway infrastructure managers, aimed at detecting the overheated bearing nodes. Such systems introduced by several railway managements (DB, SNCF, SNCB and $\mathrm{BR}$ ) consisted in installing a series of infrared radiation sensors at the track outer side.

The track-side located HABD is a part of the system containing:

$>$ the sensors measuring temperature changes detected in predetermined field of each axle box;

$>$ data processing aimed at calculating the temperature of each axle box based on the measured values; to

$$
\mathrm{H}_{\mathrm{j} . \max }=\mathrm{k}_{2} \cdot\left(10+\mathrm{P}_{\mathrm{FO}} / 3\right)
$$

Biorąc pod uwagę jakie siły mogą działać na maźniczy węzeł łożyskowy można wyciagnąć wniosek, że jego utrzymanie $\mathrm{w}$ prawidłowym stanie technicznym ma istotne znaczenie $\mathrm{z}$ punktu widzenia bezpieczeństwa jazdy. Jednym $\mathrm{z}$ objawów nieprawidłowego stanu technicznego jest wzrost temperatury pracy węzła łożyskowego ponad dopuszczalną dla bezpiecznej eksploatacji. Przyczyny tego stanu rzeczy, choć już wyżej sklasyfikowane, sprowadzają się w pierwszej mierze do zwiększonych oporów pracy łożyska (np. w wyniku zmniejszonych luzów wzdłużnych i poprzecznych w układzie łożyskowym) w stosunku do normalnej pracy.

W wyniku zwiększonej pracy tarcia, temperatura poszczególnych elementów łożyska (wałeczków, koszyków) i smaru zwiększa się, co prowadzi do stopniowej utraty własności smarnych z jednej strony (zwiększającej się pracy tarcia), ale $\mathrm{z}$ drugiej może prowadzić do drobnych, ale coraz bardziej propagujących uszkodzeń łożyska, co z kolei może prowadzić do tworzenia się opiłków metalicznych zużycia w medium smarnym i stopniowego zanieczyszczeniu smaru. $\mathrm{Z}$ tego wynika wniosek, że wszystkie czynniki (lub ich kombinacja), które powodują zwiększone opory tarcia, w efekcie nadmierne zużycie przyczyniają się do zwiększonej temperatury zespołu łożyskowego.

Jeśli smar można uznać jako element dokumentacji konstrukcyjnej, to ważna jest jego czystość w trakcie całego okresu eksploatacji. Producenci łożysk operuja w tym przypadku współczynnikiem czystości s (niem. „Sauberkeitsfaktor”) i jego wpływie na żywotność łożysk. W celu określenia współczynnika czystości potrzebny jest współczynnik zanieczyszczeń $\mathrm{V}$ (normalna czystość $\mathrm{V}=1$, podwyższona czystość $\mathrm{V}=0,5$, najwyższa czystość $V=0,3)$. Jeśli uznać zużycie elementów łożyska jako rzecz normalną, to jej faktyczna wielkość np. podczas kontrolowanej eksploatacji poligonowej (niestacjonarnej) jest zależna od rodzaju smaru oraz jego klasy czystości.

\subsection{POMIARY DIAGNOSTYCZNE PRZEZ URZAZDZENIA PRZYTOROWE W MAŹNI- CACH ZESTAWÓW KOLOWYCH UKŁA- DÓW BIEGOWYCH Y25, PRZEZNACZO- NYCH DO WAGONÓW TOWAROWYCH}

Analiza węzła łożyskowego i warunków eksploatacyjnych wagonów towarowych pozwala przedłużyć czas międzynaprawczy. Kontrolowanie temperatury zespołu łożyskowego „on-line” (na pokładzie wagonu towarowego) jest w dzisiejszych konstrukcjach wagonów towarowych praktycznie niemożliwe. W dawnych przepisach kolejowych (już unieważnionych) np. w karcie UIC 579-2 [29] jedna z metod na wykrywanie przegrzanych łożysk była metoda manualna, polegająca na uchwyceniu ręką przez rewidenta dołu korpusu 
$>$ processing of the data identifying each axle box;

$>$ a communication link for transmitting and receiving the data.

In the case of monitoring of the axle box condition by means of the track-side equipment located along the infrastructure, the European standard PN-EN 15437-1: 2009 [16] applies.

This standard categorizes the diagnostic systems into two classes, according to the vehicle speed:

$>$ the rolling stock designed for a speed up to $250 \mathrm{~km} / \mathrm{h}$ - class 2 ;

$>$ the rolling stock designed for a speed exceeding $250 \mathrm{~km} / \mathrm{h}$ - class 1 .

Classification of the rolling stock and infrastructure into two categories results, among others, from the UIC 660 [28] code.

This standard defines the minimum requirements for the HABD system/ rolling stock (RST) interface. The regulations are applicable to a $1435 \mathrm{~mm}$-gauge track and the vehicles provided with external bearings (on the outside of the wheel/wheels).

According to the PN-EN 15437-1: 2009 [16] standard the HABD must meet the following requirements:

$>$ the kinematic gauge and structure gauge in accordance with 15273-1+A1:2017 [13], 152732+A1:2017 [14] and 15273-3+A1:2017 [15];

$>$ electromagnetic compatibility requirements in accordance with PN-EN 50121-4 [19];

$>$ the environmental conditions for signaling and telecommunications in accordance with $\mathrm{PN}$ EN 50125-3:2003 [22];

$>$ the general security requirements for information technology in accordance with PN-EN 60950-1:2007[24];

$>$ general guidelines pertaining to mechanical vibration, i.e. the ground-level noise and the vibration resulting from the railway construction, according to the standard ISO 14837-1 [31].

The guidelines for installation of the HABD system are included in the Annex B to PN-EN 15437-1: 2009 [16].

Whenever possible, the HABD system should be installed on the lines or railway track sections meeting the following requirements:

$>$ the requirements pertaining to the topography and infrastructure;

$>$ the requirement of keeping appropriate distance between conventional and high-speed railway lines, in the vicinity of already existing HABD's

$>$ the requirements of HABD system operation and maintenance should be specified in the delivery terms;

$>$ the requirements of HABD system availability and reliability (to be agreed between the cus- maźnicy. Jeśli można było utrzymać rękę przez dłuższy czas, to wówczas łożyska można uznać jako nadające się do dalszej eksploatacji.

W przeciwnym wypadku, były podstawy do wykluczenia wagonu z eksploatacji, celem dokonania przez kolej podstawiającą dokładnych oględzin. Metoda ta była subiektywna i bardzo pracochłonna, jeśli weźmie się pod uwage całość prac kontrolnych, które musi wykonać rewident przed odprawą pociagu towarowego. Choć jako pomocnicza w diagnostyce może być stosowana w obecnych czasach. Jedynym skutecznym sposobem, wydawała się budowa systemu diagnostycznego, przez infrastruktury poszczególnych zarządów kolejowych, w celu wykrywania przegrzanych przymaźniczych węzłów łożyskowych. System ten polegał na instalacji po zewnętrznej stronie toru (niem. „HOA -Heisslager Ortsbestimmungs Anlagen“ lub ang „HABD-,,Hot Axlebox Detector.”) szeregu czujników, działających na promieniowanie podczerwone przez takie zarządy kolejowe jak DB, SNCF, SNCB oraz BR.

Detektor HABD, umieszczony obok toru (ang. ,trakcside"), stanowi część systemu, który obejmuje:

$>$ sensory, które mierzą temperatury zaistniałe, emitowane w zdefiniowanym polu na każdej maźnicy

$>$ przetwarzanie danych, gdzie dokonuje się obliczenia temperatury każdej maźnicy na podstawie pomierzonych wartości

> przetwarzanie danych, które identyfikuje oznaczenia każdej maźnicy

$>$ link komunikacyjny do transmisji i odbierania danych.

W przypadku monitorowania stanu maźnicy przez urządzenia przytorowe, rozmieszczone wzdłuż infrastruktury obowiązuje norma europejska PN-EN 15437-1:2009 [16].

Norma ta klasyfikuje systemy diagnostyczne na dwie klasy w zależności od prędkości pojazdu:

$>$ tabor szynowy, przystosowany do prędkości mniejszej lub równej $250 \mathrm{~km} / \mathrm{h}$ - klasa 2

$>$ tabor szynowy, przystosowany do prędkości większej od $250 \mathrm{~km} / \mathrm{h}$ - klasa 1.

Podział taboru szynowego oraz infrastruktury na dwie kategorie wynika między innymi z karty UIC 660 [30].

Norma ta definiuje minimum własności dla interfejsu pomiędzy systemem HABD i taborem kolejowym (RST). Przepisy obowiązują dla toru o prześwicie $1435 \mathrm{~mm}$ oraz ułożyskowanych zewnętrznie ( po zewnętrznej stronie koła/kół).

Zgodnie z normą PN-EN 15437-1:2009 [16] system

HABD musi spełniać następujące wymagania:

$>$ skrajni kinematycznej oraz skrajni budowli zgodnie z 15273-1+A1:2017 [13], 152732+A1:2017 [14] oraz 15273-3+A1:2017 [15] 
tomer and the equipment supplier) and

$>$ on the railway lines suitable to high speeds and the ones trafficked with hazardous goods transportation;

$>$ in the vicinity of the railway tunnels and bridges, densely populated areas, railway stations;

$>$ should take into account the weather and environmental conditions, e.g. in shadowed places or in full sunlight

A list of emergency situations reported by the HABD equipment used in Europe is specified in Table 1.

The examples of the accuracy requirements of the axle box temperature estimated by HABD equipment are listed in Table 2.

Temperature accuracy estimated by HABD equipment is specified in Table 2.
> wymagania kompatybilności elektromagnetycznej zgodnie z PN-EN 50121-4 [19],

$>$ warunki środowiskowe dla sygnalizacji i telekomunikacji zgodnie z PN-EN 50125-3:2003 [22]

$>$ wymagania ogólnego bezpieczeństwa dla technologii informatycznej zgodnie z PN-EN 60950-1:2007[24]

$>$ ogólnych wytycznych, dotyczących drgań mechanicznych tzn. hałasu przygruntowego i wibracji wynikających z systemu kolejowego wg normy ISO 14837-1 [31].

Wytyczne, dotyczące zabudowy systemu czujników HABD są podane w załączniku B normy PN-EN 15437-1:2009 [16].

Wykaz zgłoszeń alarmowych przez urządzenia HABD, stosowane w Europie

Tablica 1

A list of emergency situations reported by the HABD equipment used in Europe

Table 1

\begin{tabular}{|c|c|c|c|}
\hline \multicolumn{4}{|c|}{$\begin{array}{l}\text { Typ alarmu temperaturowego, zgłoszonego przez urządzenia HABD } \\
\text { The type of temperature alarm reported by the HAND equipment }\end{array}$} \\
\hline $\begin{array}{l}\text { Przegrzanie } \\
\text { Overheating } \\
{\left[{ }^{\circ} \mathrm{C}\right]}\end{array}$ & $\begin{array}{l}\text { Różnica temperatur pomię- } \\
\text { dzy sąsiednimi maźnicami } \\
\text { (łożyskami) zestawu kołowe- } \\
\text { go } \\
\text { Temperature difference } \\
\text { between the neighbouring } \\
\text { wheelset axle boxes (bear- } \\
\text { ings) }\left[{ }^{\circ} \mathrm{C}\right]\end{array}$ & $\begin{array}{l}\text { Podwyższona temperatura } \\
\text { Elevated temperature } \\
\left({ }^{*}\right)\left[^{\circ}\right]\end{array}$ & $\begin{array}{l}\text { Pozostałe, np. taki alarm } \\
\text { temperaturowy kiedy strony } \\
\text { pociagu mają różną tempera- } \\
\text { turę łożysk } \\
\text { The others, e.g. a temperature } \\
\text { alarm in case when the bear- } \\
\text { ing temperatures at both train } \\
\text { sides are not equal }\left[^{\circ}\right]\end{array}$ \\
\hline 95 & 56 & - & - \\
\hline 85 & 50 & $85(* *)$ & 50 \\
\hline 100 & 30 & 90 & - \\
\hline 105 & 35 & 90 & - \\
\hline
\end{tabular}

Dokladność temperatury, szacowanej przez urządzenia HABD

Tablica 2

Temperature accuracy estimated by HABD equipment

Table 2

\begin{tabular}{|c|c|c|}
\hline $\begin{array}{l}\text { L.p. } \\
\text { Item }\end{array}$ & $\begin{array}{l}\text { Zakres temperatury korpusu maźnicy } \\
\text { Axle box body temperature range }\end{array}$ & $\begin{array}{l}\text { Dokładność szacowanej temperatury } \\
\text { korpusu maźnicy } \\
\text { Accuracy of temperature estimation of } \\
\text { the axle box body }\end{array}$ \\
\hline 1. & $-50^{\circ} \mathrm{C} \div 0{ }^{\circ} \mathrm{C}$ & $\geq 10^{\circ} \mathrm{C}$ \\
\hline 2. & $0^{\circ} \mathrm{C} \div 15^{\circ} \mathrm{C}$ & $\pm 10^{\circ} \mathrm{C}$ \\
\hline 3. & $16^{\circ} \mathrm{C} \div 20^{\circ} \mathrm{C}$ & $\pm 5^{\circ} \mathrm{C}$ \\
\hline 4. & $21^{\circ} \mathrm{C} \div 90^{\circ} \mathrm{C}$ & $\pm 3^{\circ} \mathrm{C}$ \\
\hline 5. & $91^{\circ} \div 120^{\circ} \mathrm{C}$ & $\pm 5^{\circ} \mathrm{C}$ \\
\hline
\end{tabular}

2.4. DIAGNOSTIC MEASUREMENTS CARRIED OUT BY MEANS OF THE SENSORS INSTALLED IN THE VEHICLE AXLE BOXES OF THE Y25 RUNNING GEAR WHEELSETS

The requirements related to the design of a system continuously monitoring the axle box temperature with a view to detect the overheated rolling bearings of the wagon in motion and at standstill are provided by the European Standard PN-EN 15437-2 [17].

Taking into account compatibility and effectiveness of the monitoring system, this European Standard defines the requirements in the following areas:
O ile to jest możliwe, system HABD powinien być zainstalowany na liniach lub odcinkach toru kolejowego:

$>$ spełniających wymagania topograficzne i infrastruktury

$>$ spełniających utrzymanie odpowiedniej odległości pomiędzy liniami transportu kolejowego konwencjonalnego oraz z liniami kolejowymi wysokich prędkości, w pobliżu już zabudowanych HABD

> spełniających wymagania dotyczące obsługi i konserwacji dla systemu HABD powinny być określone w warunkach dostawy 
$>$ the equipment and characteristics;

$>$ the monitoring requirements;

$>$ handling and interface.

The present standard 15437-2:2012 [17] does not cover:

$>$ the systems transmitting no signal to the train driver;

$>$ the information on the on-board monitoring system construction, on the temperature measuring method and on the method of identification of the axle box in the vehicle;

$>$ the operational requirements for activation of the information recorded in the on-board monitoring system;

$>$ the operational requirements related to detection of a conflict between the track-side and on-board monitoring systems;

$>$ the requirements related to handling of the onboard system.

Vehicle equipment operating these devices must meet the relevant requirements and comply with the rolling stock deployed appliances, in accordance with the European standard PN-EN 50125-1: 2014 [21]. The design and fastening of electrical and electronic equipment, as well as that of the measuring unit installed on the bearing unit in the axle box body, must meet the requirements of the European standard PNEN 61373: 2011 [26] with a view to ensure resistance to vibration. The electronic equipment of the system must meet the requirements of the European standard PN-EN 50155: 2018 [23].

The above shows that the document specifies no requirements related to the system for detecting overheated rolling bearings of the freight wagons. The PNEN 15437-2: 2012 [17] concerns rather the locomotives, multiple units and passenger coaches. The case related to elaboration of a new, efficient and reliable system designed for monitoring overheated rolling bearings in various types of freight wagons is currently in the development or testing phase on the lines of various railway authorities, especially in Western Europe. The studies of so-called "intelligent" freight wagons equipped with diagnostic sensors, recording e.g. the temperature of the bearings, vertical and lateral acceleration in the bogie and car body areas, are promising. A significant factor is the identification of the freight train along the route and location of individual wagons in the draft of wagons. Such a location may be made together with implementation of GPS-R (Global Positioning System-Railway).

\subsection{THE MEASURES TO PREVENT OVER- HEATING OF THE ROLLING BEARINGS}

The diagnostic system is helpful in detecting the excessive temperatures that indicate overheating of the rolling bearings. It is a preventive system that already reports incorrect operation of the bearing. The supervisory service is responsible to decide on possible inter- spełniających wymagania dotyczące dyspozycyjności i niezawodności dla systemu HABD (powinny być zdefiniowane pomiędzy klientem i dostawcą urządzeń)

oraz:

$>$ na liniach kolejowych, przystosowanych do wysokich prędkości, jak również liniach obciążonych przewozami towarów niebezpiecznych

$>$ w pobliżu tuneli i mostów kolejowych, obszarów o dużym zaludnieniu, stacji kolejowych uwzględniać warunki klimatyczne i środowiskowe np. w miejscu cienia lub przy pełnym oświetleniu słonecznym.

Wykaz zgłoszeń alarmowych przez urządzenia HABD, stosowanych w Europie, jest podany w tablicy 1.

\subsection{POMIARY DIAGNOSTYCZNE PRZEZ CZUJNIKI ZAISTALOWANE NA PO- JEŹDZIE W MAŹNICACH ZESTAWÓW KOLOWYCH UKŁADÓW BIEGOWYCH RODZINY Y25}

Wymagania dotyczące projektowania systemu monitorowania stanu maźnicy w zakresie pomiaru temperatury przegrzanych łożysk tocznych w sposób ciagły podczas jazdy oraz postoju pojazdu są opisane w normie europejskiej PN-EN 15437-2 [17].

W celu kompatybilności systemu monitorowania i funkcji efektywnego monitoringu niniejsza norma europejska definiuje wymagania na następnych obszarach:

$>$ wyposażenia i charakterystyki

$>$ wymagania monitoringu

$>$ obsługi i interfejsu.

Niniejsza norma 15437-2:2012 [17] nie obejmuje:

> systemów, które nie dają sygnałów do maszynisty

$>$ jak system pokładowy monitorowania jest zbudowany, jak mierzy temperaturę oraz identyfikuje pozycje maźnicy w pojeździe

$>$ wymagań operacyjnych dotyczących uaktywnienia informacji, rejestrowanych $\mathrm{w}$ pokładowym systemie monitorowania

$>$ wymagań operacyjnych dotyczących informacji o konflikcie pomiędzy systemem monitorowania systemem monitorowania przytorowym oraz systemem pokładowym

$>$ wymagań obsługowych dla systemu pokładowego.

Wyposażenie pojazdu odnoszące się urządzeń rozmieszczonych na pokładzie taboru musi spełniać odpowiednie wymagania zgodnie $\mathrm{z}$ normą europejską PN-EN 50125-1:2014[21]. Szczególnie zaprojektowanie wyposażenia elektrycznego oraz elektronicznego, jak również mocowania z uwzględnieniem kryterium odporności na drgania i wibracje, włącznie z jednostką pomiarową zainstalowaną na zespole łożyskowym w 
ruption of the freight train traffic and its withdrawal, notifying the carrier and undertaking the efforts aimed at determining the reason of the increased operating temperature. Meanwhile, a question arises, what guidelines should be followed with a view to reduce considerably the phenomenon and thus to increase the operational, or in other words, driving safety.

It should be noted that the rolling bearings of the current manufacturers are characterized by their specific service life, expressed in kilometers. An element important for proper operation of the bearing during operation consists in correct evaluation of particular parts. Authorization of 40 or 50 -year-old bearings or combined bearings made of various elements is technically pointless and may result in wrong operation of the bearing and breakage (tearing off) of the axle pivot. Assessment of actual technical condition of so responsible parts like inner and outer rings and rollers, without determination of the criteria for external and internal defects, without the magnetic particle and ultrasonic examination, is rather pointless, as these are the parts subjected to fatigue. It applies in particular to authorization of used and yet useful bearings. It should be taken into account that the bearing assembly mounted in the axle box is distinguished by a specific fatigue limit. In this case not only the use of stainless steel, but also the surface roughness is decisive, to be determined by means of an electronic roughness measuring device during the repairs. It should be certainly assumed that at the repair stage, when the axle box inspection, maintenance and repairs are carried out, the technological culture regime equal to that maintained in the bearings factory should be kept. No parameter can be subjectively evaluated, including cleanliness of the premises where the bearings are commissioned. Cleanliness of such premises should be evaluated in accordance with the PN ISO 14644-1: 2016-03 Standard [27], that lists their cleanliness classes. The adopted version of the standard modifies the number of measuring points in the clean zone and allows each measuring point to be considered with $95 \%$ confidence, providing that at least $90 \%$ of the room or clean zone area meets the maximum limits of a given air purity class. It should be noticed that Poland committed to apply it in 2016. Replacement of brass retainers of used bearings with plastic ones (e.g. made of polyamide) may be considered. Such a modernization technology may be implemented provided that the repair plant develops a detailed methodology that should be approved by the certifying unit. The use of plastic retainers is an important modernization procedure. Such type retainers are distinguished by smaller mass than the brass ones, the bearing system emits less friction work and, in consequence, the heat emission in the entire axle box system is lower. Another advantage consists in relatively high resistance to wear. Another factor affecting proper operation of the bearings is grease. The lubricant should be approved korpusie maźnicy musi spełniać wymagania normy europejskiej PN-EN 61373:2011 [26]. Wyposażenie elektroniczne układu musi spełniać wymagania normy europejskiej PN-EN 50155:2018 [23].

$\mathrm{Z}$ przedstawionych informacji wynika, że dokument nie precyzuje wymagań, dotyczących rozwiązania systemu wykrywania przegrzanych łożysk tocznych w wagonach towarowych. Norma PN-EN 15437-2:2012 [17] jest raczej dedykowana lokomotywom, zespołom trakcyjnym oraz wagonom osobowym. Sprawa związana $\mathrm{z}$ opracowaniem nowego, wydajnego, niezawodnego systemu monitorowania przegrzanych łożysk tocznych w wagonach towarowych różnego typu jest na razie w fazie rozwoju lub testowania nowych koncepcji na liniach różnych zarządów kolejowych, zwłaszcza Europy Zachodniej.

Pewne nadzieje można wiązać $\mathrm{z}$ opracowaniami tzw. „inteligentnych" wagonów towarowych, które są wyposażone w sensory diagnostyczne, rejestrujące np. temperaturę łożysk, przyspieszenia pionowe i poprzeczne w rejonie wózka i nadwozia wagonu. Istotnym czynnikiem jest identyfikacja pociagu towarowego na trasie oraz poszczególnych wagonów w składzie pociagu. Lokalizacja ta może być zrealizowana wraz $\mathrm{z}$ wdrożeniem systemu GPS-R (Global Positioning System-Railway).

\section{5. ŚRODKI ZARADCZE PRZED GRZANIEM SIĘ LOŻYSK TOCZNYCH}

System diagnostyczny pomaga w wykrywaniu temperatur, świadczących o przegrzaniu się łożysk tocznych, jest systemem prewencyjnym, już potwierdzającym nieprawidłową pracę łożyska. Zadaniem służb nadzorujących jest podjęcie decyzji o ewentualnym przerwaniu ruchu pociagu towarowego oraz odstawieniu wagonu, powiadomieniu przewoźnika oraz uruchomieniu prac, mających na celu ustalenie przyczyny, zwiększonej temperatury pracy. W tym miejscu pojawia się pytanie, jakich wytycznych należy przestrzegać, aby to zjawisko w istotny sposób ograniczyć, a tym samym zwiększyć bezpieczeństwo eksploatacyjne, albo inaczej bezpieczeństwo jazdy.

Należy zwrócić uwagę, że łożyska toczne obecnych producentów miały i mają określoną żywotność, wyrażoną w kilometrach. Istotnym elementem prawidłowej pracy łożyska podczas eksploatacji jest prawidłowa kwalifikacja poszczególnych części. Kwalifikowanie łożysk 40 lub 50 letnich względnie kombinowanych z różnych elementów jest pozbawione większego sensu technicznego i może być przyczyną nieprawidłowej pracy łożyska oraz urwania (ukręcenia) czopa osi. Ocena faktycznego stanu technicznego bez stosowania badań magnetyczno-proszkowych oraz ultradźwiękowych takich odpowiedzialnych elementów jak pierścienie wewnętrzne, zewnętrzne oraz wałeczki bez ustalonych kryteriów wad zewnętrznych oraz wad wewnętrznych nie ma większego sensu, ponieważ są to elementy, podlegające pracy zmęczeniowej. 
according to PN-EN 12081: 2017 Standard [8], while the assembled axle box should be subjected to bench and operational tests in this regard, in accordance with PN-EN 12082: 2017 [9]. Lubricity tests of the lubricants are subject to PN-EN 14865-1 + A1: 2011 [11] or PN-EN 14865-2 + A2: 2011 [12] Standards. Therefore, the lubricant manufacturer is required to present the approval certificate upon request of the person executing the tests.

Apart from the approved grease, the following factors affect correct operation of the bearing:

$>$ contamination of the lubricant, affected by proper transportation to the place of destination and storage conditions; the lubricant storage temperature should range from $-5^{\circ} \mathrm{C}$ to + $30^{\circ} \mathrm{C}$ (according to clause 11 of the PN-EN 12081: 2017 Standard [8]), while the storage duration must not in practice exceed 24 months following the date of delivery to the customer, otherwise the batch quality is required to be checked;

$>$ cleanliness and temperature in the premises where the bearing lubricant is renewed;

$>$ thorough cleaning of all the bearing elements and housing from the old grease and other contaminants;

$>$ amount of the lubricant supplied. It should be noticed that the grease amount must comply with the requirements specified in the construction documentation and possibly in the MSD (Maintenance System Documentation). Excessive grease amount impedes operation of the bearing - the grease hinders its rotation. On the other hand, insufficient grease quantity results in rapid wear of the bearing that can quickly propagate, contributing to its damage. It can be concluded that the incorrect amount of approved grease in the bearing node may result in its increased temperature during operation. Lubricant dosing during the bearing inspection must be documented both in terms of the lubricant type (marking) and its amount supplied to the particular axle box body;

$>$ avoiding to mix various lubricant types, as in extreme cases this might result in loss of lubricating properties. Accidental mixing of two different lubricants may initiate a chemical reaction, the resulting compound of which may no longer have the required lubricating properties.

A test drive may be considered as a checking mean to verify proper operation of the axle box. For example, the Technical Conditions entitled "Assembly and periodical inspection of the NJ+NJP type bearings of the wheelsets of passenger and freight wagons" ITN -30 ed. B (the document is already revoked) [33] contains the following entry: "Once the axle box is filled with grease, the wagon test drive must be carried out. In the
Zwłaszcza kiedy istotą sprawy jest kwalifikacja łożysk tzw. staro-użytecznych. Należy wziąć również pod uwagę, że zespół łożysk montowanych w maźnicy posiada określoną granicę zmęczenia. W tym przypadku decydującym elementem nie jest tylko zastosowanie stali szlachetnej, ale również chropowatość powierzchni, którą w naprawach trzeba by określać za pomoca elektronicznego przyrządu do pomiaru chropowatości.

Bez żadnego ryzyka należy przyjąć zasadę, że na etapie naprawczym, gdzie dokonuje się przeglądu, konserwacji oraz napraw węzła maźniczego trzeba utrzymać taki sam reżim kultury technicznej jak w zakładach produkujących łożyska. Żadnego parametru nie można oceniać subiektywnie, np. czystości pomieszczenia w którym dokonuje się kwalifikowania łożysk. Czystość takiego pomieszczenia powinna być kwalifikowana wg normy PN ISO 14644-1:2016-03 [27], gdzie wymienione są klasy czystości pomieszczeń. Przyjęta wersja normy modyfikuje ilość punktów pomiarowych w strefie czystej i pozwala traktować każdy punkt pomiarowy z $95 \%$ ufnościa, że co najmniej $90 \%$ powierzchni pomieszczenia lub strefy czystej będzie spełniało maksymalne limity dla danej klasy czystości powietrza.

Zwraca się uwage na fakt, że Polska zobowiązała się do jej stosowania w 2016 roku. Wymiana koszyków mosiężnych na koszyki wykonywane $\mathrm{z}$ tworzyw sztucznych (np. koszyki poliamidowe) w łożyskach eksploatowanych może być brana pod uwagę. Wykonywanie tej technologii modernizacyjnej jest uwarunkowane opracowaniem szczegółowej metodyki przez zakład naprawczy, zatwierdzonej przez jednostkę certyfikująca. Zastosowanie koszyków z tworzyw sztucznych jest istotnym zabiegiem modernizacyjnym. Koszyki tego typu posiadają mniejszą masę od mosiężnych, wytwarzają mniej pracy tarcia w układzie łożyskowym, a tym samym przyczyniają się do mniejszej emisji ciepła w całym układzie maźniczym. Kolejną zaletą jest relatywnie duża odporność na zużycie ścierne. Kolejnym problemem, który przyczynia się do prawidłowej pracy łożysk jest smar. Smar powinien posiadać homologację wg PN-EN 12081:2017 [8] oraz przejść badania stanowiskowe oraz eksploatacyjne $\mathrm{w}$ zmontowanym węźle maźniczym zgodnie $\mathrm{z}$ normą PN-EN 12082:2017 [9]. Badania smarności smarów powinny być wykonane zgodnie $\mathrm{z}$ normą PN-EN 14865-1+A1:2011 [11] lub PN-EN 14865-2+A2:2011 [12]. W związku z tym producent smaru jest zobowiązany przedstawić świadectwo homologacyjne na żądanie wykonującego odpowiednie świadectwo (dokument) homologacyjne (y).

Oprócz zastosowanego smaru, mającego homologację, wpływ na poprawną eksploatację mają następujące czynniki: 
beginning the axle box may overheat, later on the temperature should stabilize. The initial temperature rise is explained by excessive grease amount between the bearing rollers."

This provision is doubtful at least, being not precise in terms of its content, from a technical point of view.

There relevant information regarding the following items is lacking:

$>$ what is the vehicle speed during the test drive;

$>$ what is the type of the operating section (a straight or mixed track with curved sections, what is the track length);

$>$ what is the measuring device of the initial and final temperature, before the start and after termination of the test drive, respectively;

$>$ for what freight wagon condition, i.e. empty or loaded, the test drive should be carried out;

$>$ what is the value of the stabilized temperature mentioned by the author(s)?

The author is aware of his critical opinion on the provisions of the instruction that is no longer valid. Nevertheless, the updated instructions related to the considered problems should be referred to in the current and newly developed MD documents.

It should be noted that the empty to loaded wagon mass ratio amounts approximately to $1: 4$. The bearing load is proportional to the vehicle mass and speed. Moreover, in the case of a test on fully loaded wagon, the axle pivot deflects together with the parts cooperating with it. Thus, at maximum speed of $100 \mathrm{~km} / \mathrm{h}$ the test becomes more reliable. Simulation of such a condition is difficult for the repairer, nevertheless, the operating conditions of the wagon with more loaded bearings are then best imitated. Should the test drive carried out according to the present MD instructions be considered as a criterion for correct assembly, the above-mentioned doubts must be explained. The conditions for the test run at a speed of $\mathrm{v} \pm 5 \mathrm{~km} / \mathrm{h}$ under a defined loading level must be specified, otherwise the evaluation conditions differ from one carrier to another, thus being mutually inconsistent and not comparable.

\section{CONCLUSIONS}

1. According to the presented analysis of the reasons of overheated rolling bearings assembled in the freight wagon axle boxes equipped with Y25 running gears, they are very complex and require a lot of professional knowledge of the rolling stock user, as well as its repair and maintenance service.

2. Taking into account the infrastructure of a given country and the whole EU financial promotion of the wagons guaranteeing a safe travel may be considered as reasonable option. The fee for the transportation services of the carrier possessing the rolling stock of very good technical condition and provided with a
$>$ zanieczyszczenie smaru, na który wpływ mają takie czynniki jak prawidłowy transport do miejsca przeznaczenia, warunki przechowywania; temperatura przechowywania smaru powinna wynosić od $-5^{\circ} \mathrm{C} \div+30^{\circ} \mathrm{C}$ (zgodnie $\mathrm{z}$ p. 11 normy PN-EN 12081:2017 [8]), natomiast czas przechowywania nie może być $\mathrm{w}$ praktyce dłuższy niż 24 miesiące od daty dostarczenia do zamawiającego, ponieważ $\mathrm{w}$ przeciwnym przypadku konieczne jest obligatoryjne sprawdzenie jakości partii

$>$ czystość i temperatura pomieszczeń, w których dokonuje się wymiany smaru w łożysku

$>$ dokładne oczyszczenie wszystkich elementów łożyska oraz zabudowy z poprzedniego smaru oraz innych zanieczyszczeń

$>$ ilość dozowanego smaru; należy wziąć pod uwage, że ilość smaru musi być zgodna $\mathrm{z}$ wymaganiami, określonymi $\mathrm{w}$ dokumentacji konstrukcyjnej oraz ewentualnie w Dokumentacji Systemu Utrzymania DSU; zbyt duża ilość smaru prowadzi do utrudnionej pracy łożyska, smar stanowi jakby utrudnia kolejne obroty łożyska, natomiast zbyt mała ilość smaru powoduje szybkie zużycie, które może szybko propagować, przyczyniając się do jego uszkodzeń; można tutaj postawić wniosek, że nieprawidłowa ilość homologowanego smaru w węźle łożyskowym może przyczynić się do jego podwyższonej temperatury $\mathrm{w}$ trakcie eksploatacji; dozowanie smaru podczas przeglądu łożysk musi być udokumentowane tak pod względem typu (oznaczenia) smaru, jak również ilości dozowanej $\mathrm{w}$ danym korpusie maźnicy

$>$ unikanie mieszania różnych gatunków smarów, które może doprowadzić w skrajnym wypadku do utraty własności smarnych.

Przypadkowe zmieszanie smaru jako związku chemicznego $z$ innym smarem może być zaczątkiem reakcji chemicznej, w wyniku czego powstały związek może nie posiadać już założonych własności smarnych.

Przeprowadzanie jazdy próbnej jako weryfikującej poprawność funkcjonowania węzła maźniczego może być uznane jako środek do sprawdzania temperatury węzłów łożyskowych w pojeździe. Np. w dokumencie Warunki Techniczne „Montaż i rewizja okresowa łożysk typu NJ+NJP zestawów kołowych wagonów osobowych i towarowych" ITN-30 wyd.B (dokument obecnie unieważniony) [33] znajduje się zapis następujący: „Po przettoczeniu smaru należy wagon poddać próbnej jeździe. Na próbnej jeździe początkowo maźnica może się nadmiernie nagrzewać, później temperatura powinna sie ustabilizować. Poczqtkowy wzrost temperatury tlumaczy się nadmiernq ilościq smaru między wateczkami tożysk." 
diagnostic system should be lower. This would be a significant stimulator of technical progress, driving safety and competitiveness improvement of the rail transportation as compared to the other transportation modes, especially the road transportation. Therefore, a proper transportation and financial policy should be an important element of the railway progress.

3. Proper operation of the system for detecting overheated axle box bearings is conditioned by its continuity on the transportation lines. Partial or fragmentary equipment of the transport line with the trackside sensors only on a certain part of the route is unreasonable and is equal to seeming protection of the railway infrastructure. The railway network equipped with a diagnostic system is a source of knowledge about itself, but also about the rolling stock running on it.

4. It is evident that not all issues related to causes and preventive measures have been discussed. The problems are very complex and require further detailed analysis.

5. A certain design solution potentially increasing the rolling stock safety would consist in implementation of maintenance-free TBU bearing units of high performance, that do not require maintenance up to $1,000,000 \mathrm{~km}$ traveled by a freight wagon or for a period of 8-10 years since putting the wagon into operation. However, in case of combination of adverse operating factors maintenance of allowable bearing temperature cannot be guaranteed.

\section{Bibliography / Bibliografia}

[1] Sobaś M. Wpływ omaźnicowych zestawów kołowych na bezpieczeństwo eksploatacyjne wagonów towarowych. Pojazdy Szynowe nr 4/2016

[2] Sobaś M. Zastosowanie uszczelnień filcowych we współczesnych węzłach układów biegowych pojazdów szynowych. Pojazdy Szynowe nr 1/2018

[3] Sobaś M. Wytyczne do określenia nośności osi zestawów ko owych wagonów towarowych z czopem o wymiarach Ø120×179 mm. Pojazdy Szynowe nr 2/2019

[4] Sobaś M. Analityczne określenie nośności osi zestawów kołowych wagonów towarowych. Pojazdy Szynowe $n r$ $3 / 2019$

[5] Sobaś M. Określenie ugięcia osi z czopem o wymiarach $\varnothing 120 \times 179 \mathrm{~mm}$ zestawów ko ${ }^{3}$ owych wagonów towarowych.. Pojazdy Szynowe. Nr 4/2019

[6] PN-EN 13103-1:2018. Kolejnictwo. Zestawy kołowe $i$ wózki. Część1: Zasady konstrukcji osi z czopami zewnętrznymi

[7] PN-EN 12080:2017. Kolejnictwo. Maźnice. Łożyska toczne

[8] PN-EN 12081:2017. Kolejnictwo. Maźnice. Smary

[9] PN-EN 12082:2017. Kolejnictwo. Maźnice. Badania eksploatacyjne
Zapis ten jest co najmniej problematyczny nie jest ścisły pod względem merytorycznym, z punktu widzenia technicznego.

Brak jest istotnych informacji $\mathrm{w}$ dokumencie ITN-30 wyd.-B, dotyczących:

$>$ z jaką prędkością pojazdu ma być przeprowadzana jazda próbna

$>$ na jakim odcinku pomiarowym (tor prosty, mieszany z łukami i jakiej długości)

$>$ jakim przyrządem należy mierzyć temperature poczattkową i końcową, odpowiednio przed rozpoczęciem i zakończeniem jazdy próbnej

$>$ w jakim stanie próżnym czy ładownym wagonu towarowego ma być przeprowadzona jazda próbna

$>$ jaki poziom ustabilizowania temperatury ( $\mathrm{w}$ sensie wartości) ma na myśli autor (rzy) ww. instrukcji lub inaczej jaka jest wartość temperatury ustabilizowanej względem temperatury otoczenia.

Autor zdaje sobie sprawę, że odnosi się krytycznie do zapisów, zamieszczonych już w nie stosowanej instrukcji. Jednak w już stosowanych i w nowo opracowanych dokumentach DSU, należy przywołać zaktualizowane instrukcje dotyczące omawianej problematyki.

Zwraca się uwagę na fakt, że masa wagonu w stanie próżnym wynosi w stosunku do wagonu w stanie ładownym wynosi ok. 1:4. Obciążenia na łożysku są proporcjonalne do masy oraz prędkości pojazdu. Poza tym $\mathrm{w}$ przypadku próby wykonywanej $\mathrm{z}$ wagonem maksymalnie obciążonym, dochodzi do ugięcia czopa osi oraz elementów współpracujących, co przy maksymalnej prędkości wynoszącej $100 \mathrm{~km} / \mathrm{h}$, czyni próbę bardziej wiarygodną. Trudno jest naprawiającemu zasymulować taki stan, ale prawdą jest, że są to możliwe warunki eksploatacyjne wagonu, przy których łożyska są szczególnie obciążone. Jeśli jako kryterium poprawności montażu przyjmuje się przeprowadzenie jazdy próbnej w obecnych instrukcjach będących częścią DSU, to wówczas wszystkie ww. wątpliwości muszą być wyjaśnione. Warunki przeprowadzenia jazdy próbnej z prędkością $\mathrm{v} \pm 5 \mathrm{~km} / \mathrm{h}$ oraz $\mathrm{w}$ zdefiniowanym stanie załadowania muszą być określone, w przeciwnym wypadku warunki oceny są różne dla różnych przewoźników, wzajemnie niezgodne i nie dające się porównać.

\section{WNIOSKI}

1. Jak widać $z$ przedstawionej analizy przyczyny przegrzanych łożysk tocznych, zamontowanych w maźnicach wózków wagonów towarowych, wyposażonych w układy biegowe typu Y25 sa zagadnieniem bardzo złożonym i wymagają od użytkującego tabor kolejowy oraz przeprowadzającego jego naprawy i konserwacje dużej wiedzy fachowej. 
[10] PN-EN 14363+A1:2019. Kolejnictwo. Badania $i$ symulacje modelowe właściwości dynamicznych przed dopuszczeniem do ruchu. Badania własności dynamicznych i próby stacjonarne

[11] PN-EN 14865-1+A1:2011. Kolejnictwo. Smary do maźnic. Część 1: Metoda badania smarności smarów

[12] PN-EN 14865-2+A2:2011. Kolejnictwo. Smary do maźnic. Część 2: Metoda badania stabilności mechanicznej przy ruchu pojazdu z prędkościq do $200 \mathrm{~km} / \mathrm{h}$

[13] PN-EN 15273-1+A1:2017. Kolejnictwo. Skrajnie. Część 1: Postanowienia ogólne. Wymagania wspólne dla infrastruktury i pojazdów szynowych

[14] PN-EN 5273-2+A1:2017. Kolejnictwo. Skrajnie. Część 2: Kolejnictwo. Skrajnia pojazdów szynowych

[15] PN-EN 15273-3+A1:2017. Kolejnictwo. Skrajnie. Część3: Kolejnictwo. Skrajnie budowli

[16] PN-EN 15437-1:2009. Kolejnictwo. Monitorowanie stanu maźnicy. Wymagania dotyczace interfejsu $i$ projektowania. Część 1: Urzadzenia przytorowe $i$ maźnice pojazdów szynowych

[17] PN-EN 15437-2:2012. Kolejnictwo. Monitorowanie stanu maźnicy. Wymagania dotyczace interfejsu $i$ projektowania. Część 2: Wymagania dotyczace eksploatacji systemów pokładowych do monitorowania temperatury

[18] PN-EN 50121-3-1:2017. Zastosowania kolejowe. Kompatybilność elektromagnetyczna. Czesść 3-1: Tabor-Pociag i kompletny pociag

[19] PN-EN 50121-4:2017. Zastosowania kolejowe. Kompatybilność elektromagnetyczna. Czesść 4:Emisja $i$ odporność urzqdzeń sterowania ruchem kolejowym oraz telekomunikacji

[20] PN-EN 50124-3:2003. Zastosowania kolejowe. Warunki środowiskowe stawiane urzadzeniom. Część 3:Wyposażenie dla sygnalizacji i telekomunikacji

[21] PN-EN 50125-1:2014. Zastosowania kolejowe. Warunki środowiskowe stawiane urzadzeniom. Część 1:Tabor $i$ wyposażenie poktadowe

[22] PN-EN 50125-3:2003. Zastosowania kolejowe. Warunki środowiskowe stawiane urzqdzeniom. Cześć 3: Wyposażenie dla sygnalizacji i telekomunikacji

[23] PN-EN 50155:2018. Zastosowanie kolejowe. Tabor. Wyposażenie elektroniczne

[24] PN-EN 60950-1:2007. Zastosowania kolejowe. Urzadzenie techniki informatycznej. Bezpieczeństwo. Część 1: Wymagania podstawowe

[26] PN-EN 61373:2011. Zastosowania kolejowe. Wyposażenie taboru kolejowego. Badania odporności na udary mechaniczne $i$ wibracje

[27] PN ISO 14644-1:2016-03. Pomieszczenie czyste $i$ zwiqzanie z nimi środowiska kontrolowane

[28] Karta UIC 510-1. Wagony towarowe. Uktad biegowy. Normalizacja. 9-te wydanie z 1.01.78. 14 zmian od 1.01.80 do 1.07.97

[29] Karta UIC 579-2. Conditions for the technical transfer inspection of wagons. Cancelled 1.02.2003

[30] Karta UIC 660. Przepisy dotyczqce zapewnienia kompatybilności technicznej dla pociagów dla stosowania wysokiej prędkości. 2-gie wydanie. Luty 2002. sierpień 2002.
2. Z punktu widzenia infrastruktury danego kraju, jak i UE jako całości, za sensowne uważa się promowanie finansowe wagonów, gwarantujących bezpieczną jazdę. Opłata finansowa za usługi przewozowe dla przewoźnika dysponującego taborem kolejowym o bardzo dobrym stanie technicznym oraz wyposażonego w system diagnostyczny powinny być mniejsze. Byłby to istotny stymulator postępu technicznego, bezpieczeństwa jazdy i poprawy konkurencyjności transportu kolejowego w stosunku do innych rodzajów transportu zwłaszcza drogowego. Tak więc odpowiednio prowadzona polityka przewozowo-finansowa powinna być istotnym elementem postępu kolejnictwa.

3. Warunkiem prawidłowego działania systemu do wykrywania przegrzanych łożysk maźniczych jest jego ciagłość na liniach przewozowej (liniach przewozowych). Częściowe lub wycinkowe wyposażenie linii przewozowej tzn. na pewnym odcinku trasy w czujniki przytorowe nie ma sensu i prowadzi do pozornego zabezpieczania infrastruktury kolejowej. Sieć kolejowa, wyposażona w system diagnostyczny, jest źródłem wiedzy o niej samej, ale również o kursującym po niej taborze kolejowym.

4. Ze zrozumiałej przyczyny nie wszystkie zagadnienia dotyczące przyczyn i środków zapobiegawczych zostały omówione. Problematyka jest bardzo złożona i wymaga dalszych szczegółowych analiz.

5. Pewnym wyjściem konstrukcyjnym, zwiększającym bezpieczeństwo kursującego taboru byłoby wdrożenie bezobsługowych zespołów łożyskowych TBU o dużej wydajności, które nie wymagają przeglądów do $1000000 \mathrm{~km}$ przejechanych kilometrów przez wagon towarowy lub $8 \div 10$ lat od chwili uruchomienia wagonu do eksploatacji. Jednak nie ma dalej gwarancji, że łożyska te mogą przekroczyć dopuszczalnej temperatury przy złożeniu się niekorzystnych czynników eksploatacyjnych.

[31] ISO 14387-1:2005. Ground-borne noise and vibration arising from rail systems. Part 1: General guidance.

[32] ISO 15243:2017. Łożyska toczne. Uszkodzenia $i$ awarie. Warunki, cechy i przyczyny.

[33] Warunki techniczne ITN-30.wyd. B. Lożyska toczne. Montaż i rewizja okresowa łożysk typu NJ+NJP zestawów kołowych wagonów osobowych $i$ towarowych. Centrala Handlowa Przemystu Precyzyjnego „PREMA”. Warszawa 1980. 